\title{
D-Alanyl-lipoteichoic acid in Lactobacillus casei: secretion of vesicles in response to benzylpenicillin
}

\author{
Jordan H. Pollack, Alphonsus S. Ntamere and Francis C. Neuhaus* \\ Department of Biochemistry, Molecular Biology and Cell Biology, Northwestern University, Evanston, \\ Illinois 60208, USA
}

(Received 12 December 1991; revised 14 January 1992; accepted 27 January 1992)

\begin{abstract}
Vesicles containing lipoteichoic acid (LTA) have been isolated from Lactobacillus casei ATCC 7469 grown in the presence of either benzylpenicillin or D-cycloserine. These cell wall antibiotics enhanced the rate of LTA and lipid secretion 6.7 times, whereas chloramphenicol inhibited their release. The formation of these vesicles from peripheral and septal wall regions did not appear to be the result of bacteriolysis. The vesicle composition of LTA and lipid was similar to that of the cytoplasmic membrane whereas the protein composition was dissimilar. The size of these vesicles ranged from 20 to $40 \mathrm{~nm}$ and the length of LTA ranged from 5 to 50 glycerol phosphate residues. The isolation of these vesicles provides a potential in vitro acceptor system for studying the D-alanylation of lipoteichoic acid.
\end{abstract}

\section{Introduction}

Lipoteichoic acid (LTA) appears to play a vital role in bacterial growth. It has been postulated that this polymer functions in the regulation of autolytic activity (Cleveland et al., 1975, 1976; Höltje \& Tomasz, 1975), binding of $\mathrm{Mg}^{2+}$ for enzyme function (Lambert et al., 1977), and assembly of wall polymers (Fiedler \& Glaser, 1974; Hancock \& Baddiley, 1976). The D-alanine esters of LTA may provide one of the mechanisms for modulating these functions. To study the pathway for the D-alanylation of LTA in Lactobacillus casei 7469 (Ntamere et al., 1987), it was proposed that vesicles secreted in the presence of penicillin might provide an in vitro acceptor system that would conserve the in vivo organization of the LTA and associated proteins.

Lactobacilli, bacilli and streptococci spontaneously secrete LTA into the culture medium during exponential growth (Joseph \& Shockman, 1975; Markham et al., 1975; Tomasz \& Waks, 1975; Horne et al., 1977; Horne \& Tomasz, 1977, 1979; Straus et al., 1977; Alkan \& Beachey, 1978; Hakenbeck et al., 1978; Shockman et al., 1978; Waks \& Tomasz, 1978; Jacques et al., 1979; Kessler \& Shockman, 1979; Kessler \& van de Rijn 1981;

* Author for correspondence. Tel. (708) 4915656 ; fax (708) 4671380.

Abbreviation: LTA, lipoteichoic acid.
Brissette et al., 1982; Wicken et al., 1982; Card \& Finn, 1983). This secretion is greatly stimulated during the interruption of cell wall synthesis by penicillin (Horne $e t$ al., 1977; Alkan \& Beachey, 1978; Waks \& Tomasz, 1978; Horne \& Tomasz, 1979; Nealon et al., 1986; Al-Obeid et al., 1990; Leon \& Panos, 1990). The process of secretion is not the result of bacteriolysis since this response is seen by penicillin-tolerant or lysis-deficient bacteria (Horne \& Tomasz, 1977; Brissette et al., 1982). Since LTA may regulate cellular autolytic activity, the secretory process may be involved in the control of autolysis and cell division in these organisms (Horne \& Tomasz, 1977; Shockman et al., 1978; Tomasz, 1979).

In addition to the release of LTA, penicillin also stimulates the secretion of lipids (Hebeler et al., 1973; Veerkamp, 1976; Horne et al., 1977; Horne \& Tomasz, 1977; Cabacungan \& Pieringer, 1980; Brissette et al., 1982; Rogers et al., 1983; Brissette \& Pieringer, 1985) and proteins (Hakenbeck et al., 1983). In Streptococcus mutans BHT, the major lipids secreted into the culture medium during inhibition of growth by penicillin are diglucosyldiacylglycerol, monoglucosyldiacylglycerol, phosphatidylglycerol and diphosphatidylglycerol (Cabacungan \& Pieringer, 1980; Brissette et al., 1982). Rozgonyi et al. (1990) observed that penicillin greatly stimulated the release of anteiso-fatty-acid-containing lipids in Staphylococcus aureus SG 511. In Streptococcus pneumoniae R6, a complex set of membrane-bound 
cellular proteins is co-secreted with LTA and lipid into the medium from this autolysin-deficient strain (Hakenbeck et al., 1983). Thus, inhibition by penicillin of peptidoglycan synthesis in a number of organisms causes enhanced secretion of LTA, lipids and protein.

This communication describes the secretion, isolation and partial characterization of these vesicles from L. casei 7469. It is our goal to study the mechanism of D-alanylation in reconstituted systems using these vesicles with recombinant $D$-alanine-activating enzyme (M. P. Heaton and F. C. Neuhaus, unpublished observations) and the $D$-alanine:membrane acceptor ligase (Linzer \& Neuhaus, 1973).

\section{Methods}

Materials. L- $\left[{ }^{35} S\right]$ Methionine (Trans $\left.{ }^{35} \mathrm{~S}-1 \mathrm{abel}\right)\left(600 \mathrm{Ci} \mathrm{mmol}^{-1}\right)$, $L_{-}\left[{ }^{3} \mathrm{H}\right]$ methionine $\left(12 \mathrm{Ci} \mathrm{mmol}^{-1}\right),\left[1,3-^{14} \mathrm{Clglycerol}\left(50 \mathrm{mCi} \mathrm{mmol}^{-1}\right)\right.$ and $\mathrm{D}-\left[1{ }^{-14} \mathrm{C}\right] \mathrm{glucosamine}$ hydrochloride $\left(45 \mathrm{mCi} \mathrm{mmol}^{-1}\right)(1 \mathrm{mCi}=$ $37 \mathrm{MBq}$ ) were purchased from ICN Biomedicals. D-Cycloserine, chloramphenicol and benzylpenicillin were purchased from Calbiochem-Behring. Tryptone and yeast extract were purchased from Difco. Metrizamide was purchased from Aldrich. Acrylamide solution $(30 \%$, w/v) was purchased from 5 Prime $\rightarrow 3$ Prime Inc., Boulder, Col., USA. Spurr's embedding medium was from Ladd Research Industries, Burlington, Vt., USA. The monoclonal antibody to LTA was the generous gift of Dr G. D. Shockman.

Preparation of vesicles, membranes and labelled cells. Lactobacillus casei ATCC 7469, obtained from the American Type Culture Collection, was grown in LC broth consisting of $2 \%(w / v)$ tryptone, $1 \%$ (w/v) yeast extract, $2 \%$ (w/v) glucose, $150 \mathrm{~mm}-\mathrm{NaCl}, 40 \mathrm{~mm}-\mathrm{KH}_{2} \mathrm{PO}_{4}$ and salts $\left(1.6 \mathrm{~mm}-\mathrm{MgSO}_{4}, 59 \mu \mathrm{M}-\mathrm{MnSO}_{4}, 9 \mu \mathrm{M}-\mathrm{FeSO}_{4}\right)$. The pH was adjusted to 6.4 with $\mathrm{NaOH}$. For the preparation of vesicles, a culture $(250 \mathrm{ml})$ was grown to an optical density of $0.2(540 \mathrm{~nm})$ at $37^{\circ} \mathrm{C}$ and $5.4 \mu \mathrm{M}-\left(2.0 \mu \mathrm{g} \mathrm{ml}^{-1}\right)$ benzylpenicillin was added to the culture. After $4 \mathrm{~h}$, the culture was centrifuged at 5000 r.p.m. for $20 \mathrm{~min}$ to remove cells. The vesicles were collected by centrifugation at $250000 \mathrm{~g}$ for $1.5 \mathrm{~h}$. They were suspended in $5 \mathrm{mM}$-piperazine/acetate buffer ( $\mathrm{pH} \mathrm{6.4)}$ containing $150 \mathrm{mM}-\mathrm{NaCl}$ and the suspension was centrifuged at $5000 \mathrm{~g}$ to remove any remaining cells. After sedimenting the vesicles a second time they were purified on a step gradient $(15,30,35$ and $45 \%$, w/v) of metrizamide at $250000 \mathrm{~g}$ for $2 \mathrm{~h}$. The vesicles were collected, suspended in the above buffer, and stored at $4{ }^{\circ} \mathrm{C}$.

For the preparation of labelled cells, $10 \mathrm{ml}$ cultures in $\mathrm{LC}$ broth were grown with either $5 \mu \mathrm{Ci} \mathrm{D}-\left[1-{ }^{14} \mathrm{C}\right]$ glucosamine, $10 \mu \mathrm{Ci}\left[1,3-{ }^{-14} \mathrm{C}\right]$ glycerol or $480 \mu \mathrm{Ci} L-\left[{ }^{35} S\right]$ methionine $(1 \mu \mathrm{Ci}=37 \mathrm{kBq})$ for seven generations at $37^{\circ} \mathrm{C}$. The labelled cells were harvested by centrifugation and washed three times in piperazine/acetate buffer (pH 6.4). Membranes from $L$. casei 7469 were prepared according to the procedures described by Reusch \& Neuhaus (1971) and Linzer \& Neuhaus (1973). For membranes isolated from cells grown in the presence of penicillin, cultures were grown as described above in the presence of $5.4 \mu \mathrm{M}$ benzylpenicillin.

Release of labelled cellular components. To measure the kinetics of release or secretion of labelled cellular components in response to antibiotics, samples of labelled cells were suspended in fresh LC medium $(10 \mathrm{ml})$ to an optical density of 0.7 and grown at $37^{\circ} \mathrm{C}$. At $110 \mathrm{~min}$ antibiotic was added to the growing culture. Aliquots $(1 \mathrm{ml})$ were removed and centrifuged in a Beckman Microfuge for $5 \mathrm{~min}$, and the amounts of radiolabel in these aliquots were quantified.
Electron microscopy. For transmission electron microscopy, cells and vesicles were fixed with a combination of glutaraldehyde $(2.5 \%, \mathrm{v} / \mathrm{v})$ and osmium tetroxide $(1 \%, w / v)$ in 50 mM-PIPES buffer $(\mathrm{pH} \mathrm{7.5)}$ for $1.5 \mathrm{~h}$ at $4{ }^{\circ} \mathrm{C}$. After washing with buffer, the samples were post-fixed in $1 \%$ osmium tetroxide overnight. The pellets were washed three times in buffer and were embedded in $2 \%(w / v)$ agarose. The agarose pellets were dehydrated in a graded series of acetone concentrations, embedded in Spurr's low viscosity medium and sectioned (silver-gold) on an MT-2 ultramicrotome (Ivan Sorvall). The sections were stained in $2 \%(\mathrm{w} / \mathrm{v})$ uranyl acetate for $10 \mathrm{~min}$ followed by lead citrate (Reynolds, 1963) for $10 \mathrm{~min}$ and examined in a JEOL JEM-100 CX 11 transmission electron micrọscope at $80 \mathrm{kV}$.

Monoclonal antibody absorption. Monoclonal antibody against triglycerol diphosphate (Jackson et al., 1980) was serially diluted in water. Equal volumes of antibody solution and vesicle suspension, labelled with either $\left[1,3-{ }^{14} \mathrm{C}\right]$ glycerol or $\mathrm{L}-\left[{ }^{3} \mathrm{H}\right]$ methionine, were allowed to incubate at $37^{\circ} \mathrm{C}$ for $2 \mathrm{~h}$. Each sample was then collected on a $0.2 \mu \mathrm{m}$ filter, washed with water, and the radiolabel on the filter and in the filtrate were quantified.

Analytical methods. The distribution of polymer lengths in LTA was determined by a modification of the methods described by Min \& Cowman (1986), Wolters et al. (1990), and Maurer \& Mattingly (1991). LTA was extracted with $40 \%(\mathrm{w} / \mathrm{v})$ phenol/water according to the procedure of Fischer et al. (1983) and chemically deacylated with $15 \%$ $\mathrm{NH}_{4} \mathrm{OH}$ at $20^{\circ} \mathrm{C}$ for $12 \mathrm{~h}$. The samples were taken to dryness at $60^{\circ} \mathrm{C}$, dissolved in water, and analysed by PAGE on a $20 \%$ (w/v, acrylamide) gel ( $1.5 \mathrm{~mm}$ thickness) using an electrode buffer of $0.25 \mathrm{M}$-Tris/borate (pH 8.2). The samples were electrophoresed at $32 \mathrm{~V} \mathrm{~cm}^{-1}$ until the phenol red tracking dye was $1 \mathrm{~cm}$ from the bottom of the gel. The ladders of deacylated LTA were visualized by the alcian blue-silver stain of Min \& Cowman (1986) as described by Wolters et al. (1990). Similar results were obtained by chemical deacylation of the LTA samples with $0 \cdot 1 \mathrm{M}-\mathrm{NaOH}$ for $1 \mathrm{~h}$ at $60^{\circ} \mathrm{C}$. The average chain length of LTA was determined from the ratio of phosphorus to glycolipid as described by Fischer et al. (1980). D-Alanine was determined by the procedure of Diven et al. (1964). Membrane proteins were resolved by SDS-PAGE by the method of Laemmli (1970) as described by Garfin (1990) and stained with Coomassie brilliant blue R-250. Glycolipids and phospholipids were identified by thin-layer chromatography in chloroform/methanol/water (65:25:4, by vol.) (Nakano \& Fischer, 1977) and butanol/acetic acid/water (12:3:5, by vol.) (Brautigan et al., 1981).

\section{Results}

\section{Secretion and isolation of vesicles}

The secretion of vesicles from $L$. casei 7469 can be observed in photomicrographs of penicillin-treated cultures (Fig. 1). They were secreted from peripheral wall $(a)$, septum $(b)$ and regions of wall enlargement $(c)$. From these micrographs, it would appear that they are released from the cell surface as vesicular structures. For example, in the grossly deformed septal region the vesicles can be observed to be secreted into the peptidoglycan matrix (Fig. $1 b$ ). The vesicles were isolated from the culture medium after growth of the organism in the presence of benzylpenicillin and were partially purified by density gradient centrifugation on a step gradient of metriz- 


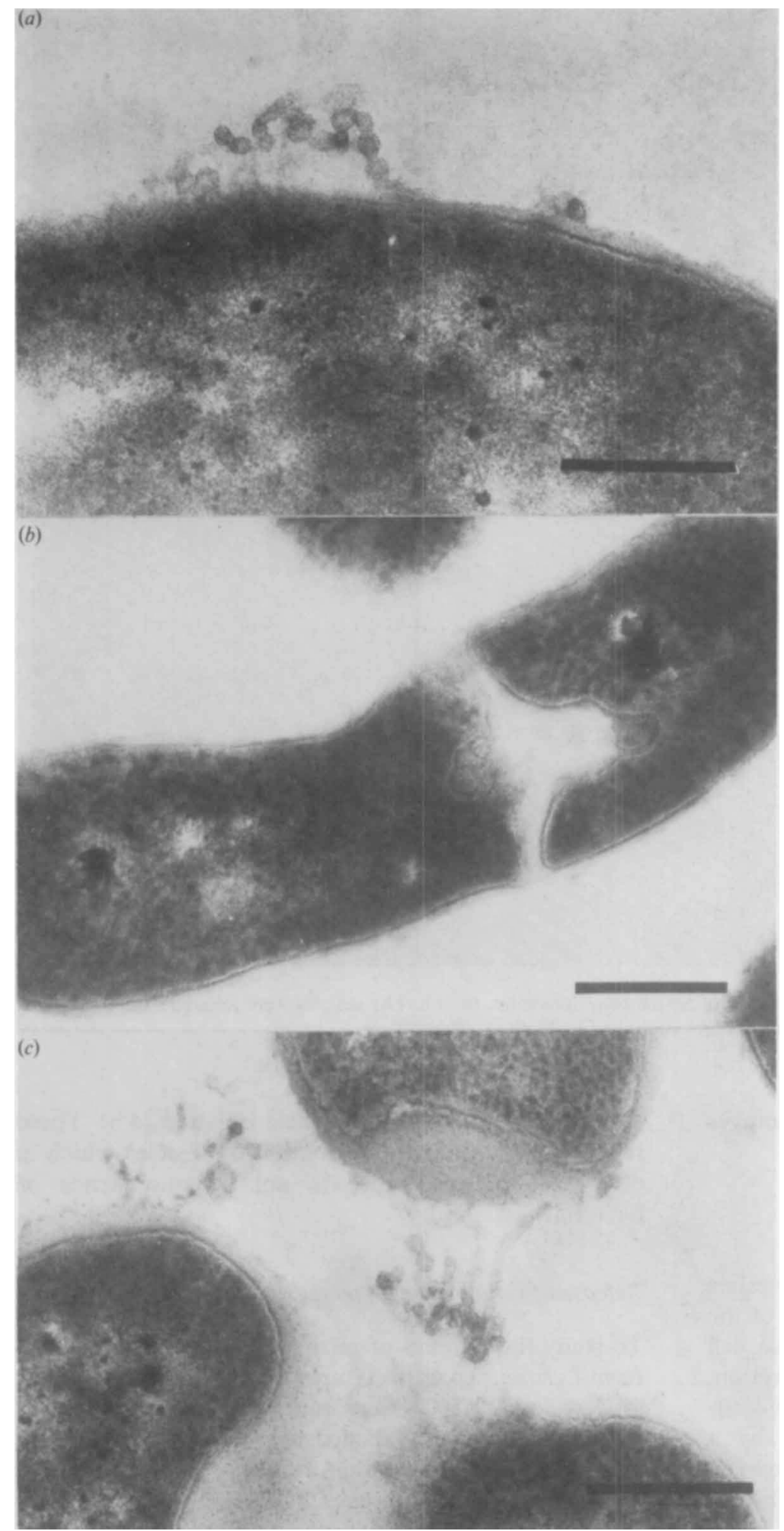

Fig. 1. Electron micrographs of penicillin-treated cells of $L$. casei. The culture was treated with $5.4 \mu \mathrm{M}$ benzylpenicillin and grown for $4 \mathrm{~h}$. The three panels, (a) peripheral, (b) septal and (c) regions of wall enlargement, illustrate the secretion of vesicular structures. Bars, $200 \mathrm{~nm}$. 


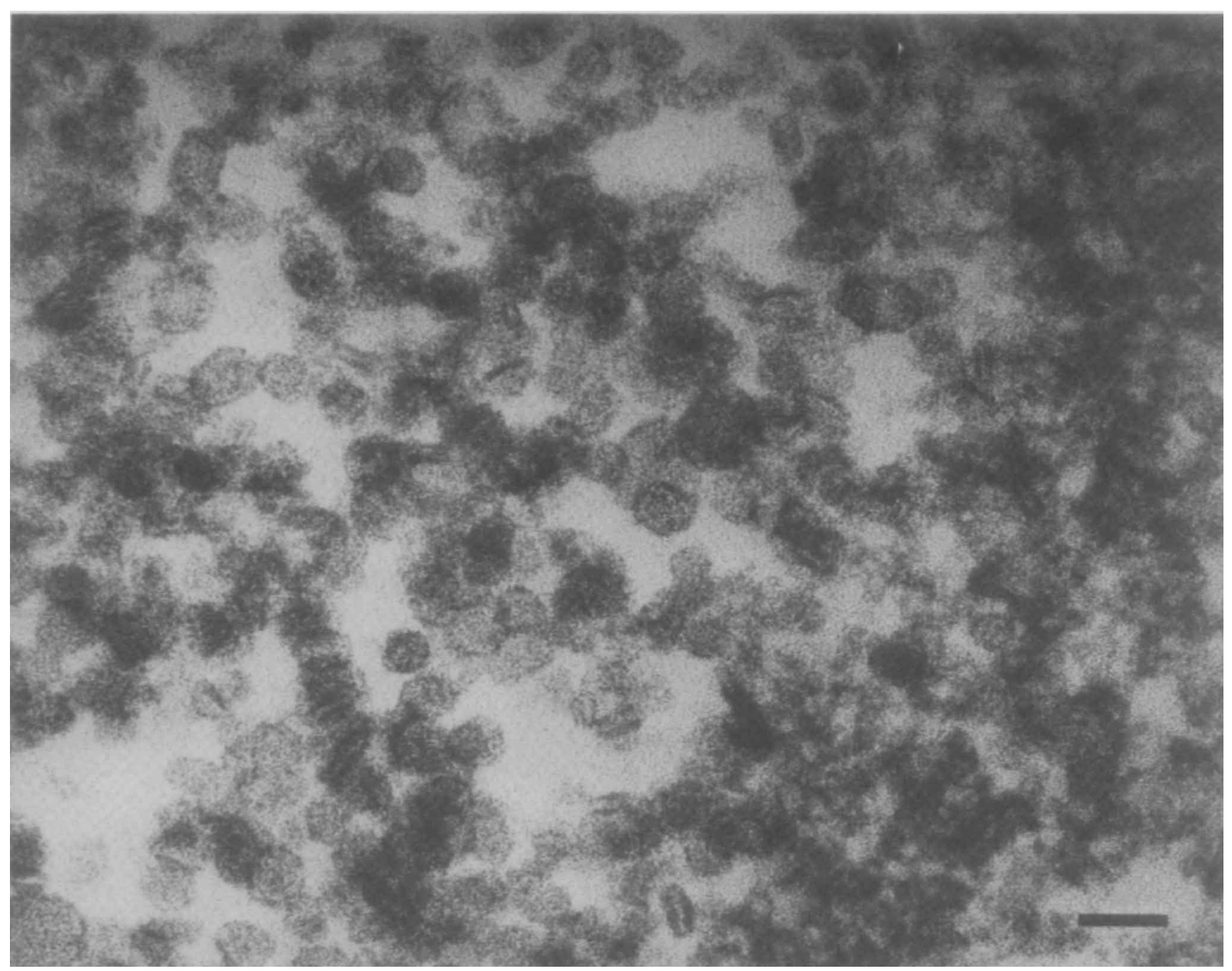

Fig. 2. Vesicles isolated from $L$. casei grown in the presence of $5.4 \mu \mathrm{M}$-benzylpenicillin for $4 \mathrm{~h}$. The vesicles were isolated from the metrizamide gradient and processed according to the procedures described in Methods. Bar, $50 \mathrm{~nm}$.

amide (see Methods). The size of these vesicles ranges from 20 to $40 \mathrm{~nm}$ (Fig. 2).

\section{L. casei as a tolerant organism}

Evidence that bacteriolysis is not the cause of vesicle formation is shown in Fig. 3. If gross disruption of the PG matrix and lysis were the cause of vesicle release, cell death would be concurrent with apparent secretion. However, if $L$. casei 7469 is tolerant to $5.4 \mu \mathrm{M}$ benzylpenicillin, vesicle formation must occur by a mechanism different from that in cellular lysis. The MIC of this $\beta$-lactam is $2.2 \mu \mathrm{M}$ (Ntamere et al., 1987). In Fig. 3, the no. of c.f.u. are compared with optical density. From these growth experiments, the ratio of c.f.u./optical density was constant from the time of penicillin application to the time of vesicle isolation $(4 \mathrm{~h})$. These results suggest that the formation of vesicles which is described in this paper is not a consequence of bacteriolysis.

\section{Release of cellular constituents from labelled cells}

To study the kinetics of release of cellular constituents from $L$. casei, separate cultures were labelled with either $\left[{ }^{14} \mathrm{C}\right]$ glycerol, $\left[{ }^{14} \mathrm{C}\right]$ glucosamine or $\left[{ }^{35} \mathrm{~S}\right]$ methionine. Growth of these radiolabelled cells in fresh culture media provided a system for monitoring the release of labelled constituents in the presence of three antibiotics. Inhibition of growth by either penicillin or D-cycloserine enhanced the secretion of glycerol-labelled material (Fig. $4 a$ ). This enhancement was characterized with a $t_{1 / 2}$ of 

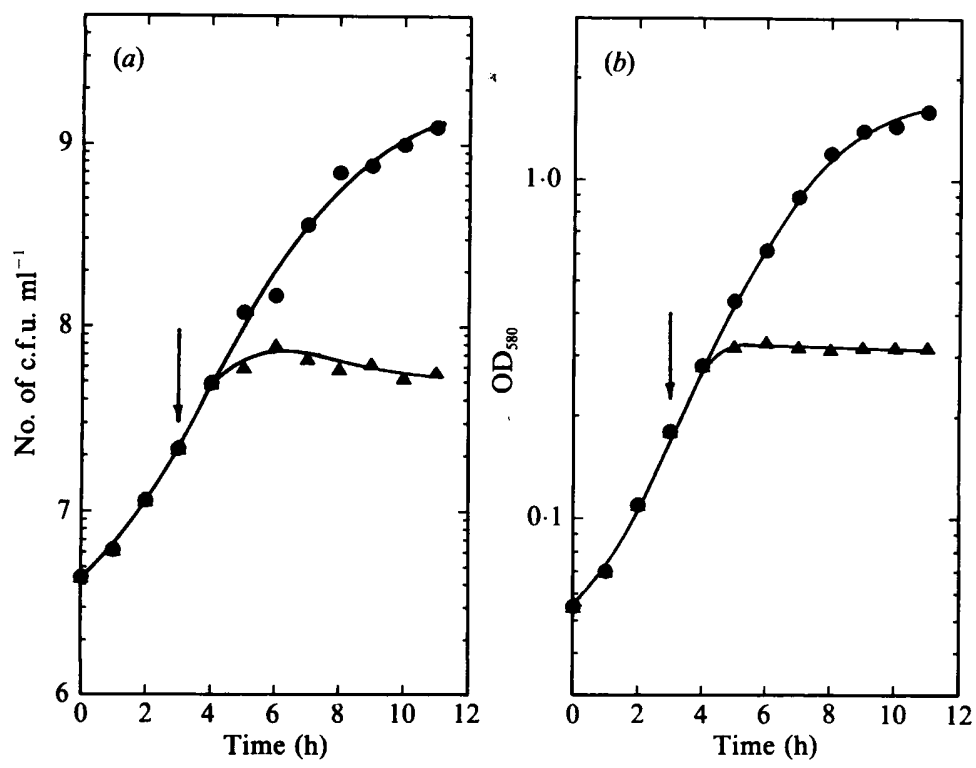

Fig. 3. Tolerance of $L$. casei to benzylpenicillin. The no. of c.f.u. and the optical density of the cultures are presented in $(a)$ and $(b)$, respectively. At $3 \mathrm{~h}(\downarrow)$, $5.4 \mu \mathrm{M}$-benzylpenicillin was applied to the exponential-phase culture $(\boldsymbol{\Delta})$. For comparison, the control culture $(\bullet)$ is shown.
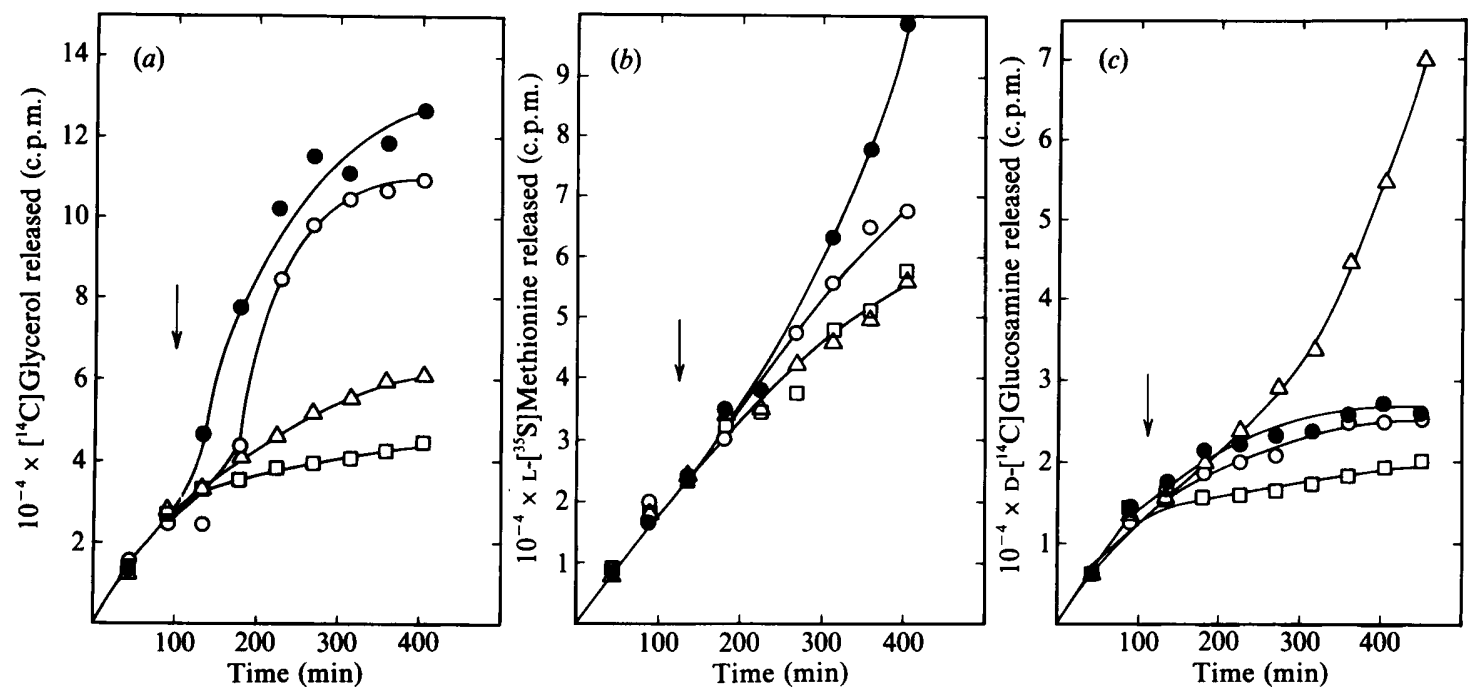

Fig. 4. Effects of benzylpenicillin, D-cycloserine and chloramphenicol on the release of glycerol-labelled (a), L-methionine-labelled (b), and D-glucosamine-labelled $(c)$ cellular components. Pre-labelled cells were washed and grown in fresh culture medium as described in Methods. The release of radiolabel (c.p.m. $\left.\mathrm{ml}^{-1}\right)$ was measured in $(a)$ with $\left[{ }^{14} \mathrm{Clglycerol-labelled}\left(2.02 \times 10^{4}\right.\right.$ c.p.m. $)$, in $(b)$ with L- $\left[{ }^{35}\right.$ S $]$ methionine-labelled $\left(2.07 \times 10^{6}\right.$ c.p.m. $)$ and in $(c)$ with $\mathrm{D}-\left[{ }^{14} \mathrm{C}\right]$ glucosamine-labelled $\left(1.12 \times 10^{6}\right.$ c.p.m. $)$ cells. The radiolabelled cells were added to $10 \mathrm{ml}$ of LC medium (Methods). At the arrow, either 5.4 $\mu \mathrm{M}$-benzylpenicillin (O), 5.4 $\mu \mathrm{M}$-D-cycloserine $(\theta)$ or $50 \mu \mathrm{M}$ chloramphenicol $(\square)$ was added to labelled exponential phase cultures of $L$. casei (control, $\Delta$ ). The amount of released radiolabel was measured according to the procedure described in Methods.

$88 \mathrm{~min}$ whereas the release of this material from control cells was characterized with a $t_{1 / 2}$ of $590 \mathrm{~min}$. The turnover of this material in the control culture was $20.8 \%$ per generation (Ntamere et al., 1987). In contrast to penicillin and D-cycloserine, chloramphenicol inhibited the release of glycerol-labelled material when compared with that in the control culture (Fig. 4a). Thus, the two inhibitors of cell wall synthesis, D-cycloserine and benzylpenicillin, promote the secretion of glycerollabelled constituents from inhibited cells.

Penicillin and D-cycloserine also stimulated the release of ${ }^{35}$ S $]$ methionine-labelled proteins by 10 and $20 \%$, respectively (Fig. 4b). The kinetics for release of glycerol-labelled material in the presence of D-cycloserine and penicillin are distinctly different from those observed with methionine-labelled cells. Each of the cell 


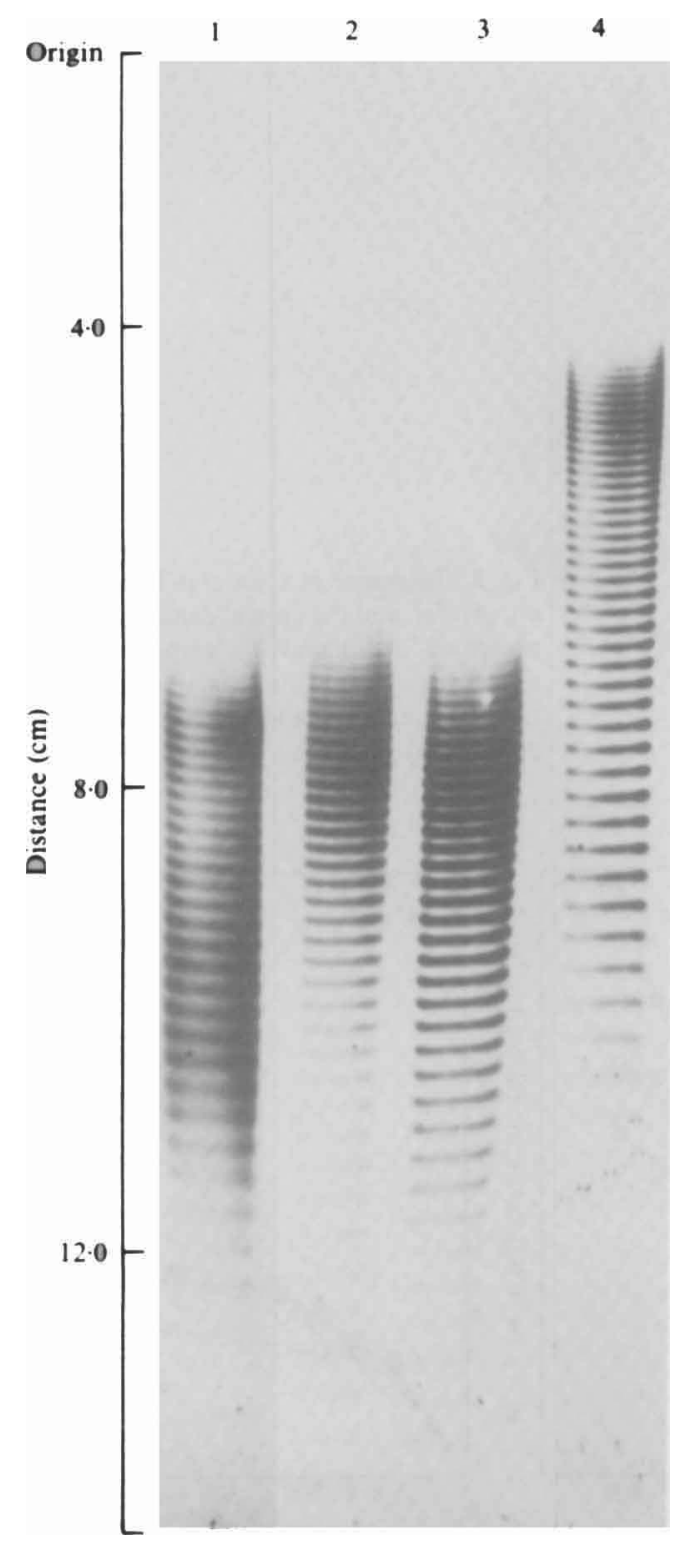

Fig. 5. Profile of chemically deacylated LTA. After deacylation of the LTA, the sample was resolved as described in Methods. LTA from either vesicles (lane 3), membranes from cells grown in the absence of penicillin (lane 1), or membranes from cells grown in the presence of $5.4 \mu \mathrm{M}$-penicillin (lane 2) is shown. For comparison wall teichoic acid extracted with $5 \%$ trichloroacetic acid from $B$. subtilis is shown in lane 4. The amount of LTA phosphorus in lanes 1,2 and 3 is $0.4 \mu \mathrm{g}$. Oligomers with less than 5 repeat units are not visualized by the alcian blue method (Wolters et al., 1990). wall antibiotics as well as chloramphenicol inhibited the turnover of pre-labelled peptidoglycan and hence its release into the medium (Fig. $4 c$ ). The kinetics of $\left[{ }^{14} \mathrm{C}\right]$ glucosamine-labelled peptidoglycan release in the control reflected the exponential growth of the culture. The fact that D-cycloserine and penicillin inhibit release of pre-existing peptidoglycan further supports the conclusion that bacteriolysis is not occurring in the growth arrested culture. Thus, in addition to stimulating the release of glycerol-labelled material, these cell wall inhibitors also stimulated a small release of methioninelabelled protein.

\section{Characterization of vesicles}

LTA was isolated from vesicles by phenol/water extraction and the distribution of chain lengths was examined by the electrophoretic procedure described in Methods. The heterogeneous profile of chemically deacylated LTA from vesicles resembled that derived from membranes (Fig. 5). Although the average chain length determined from the phosphorus/glycolipid ratio was $38 \pm 3$, no predominant length was observed. The polyglycerol phosphate moieties were estimated to range from 5 to 50 residues in length. For comparison, wall teichoic acid 

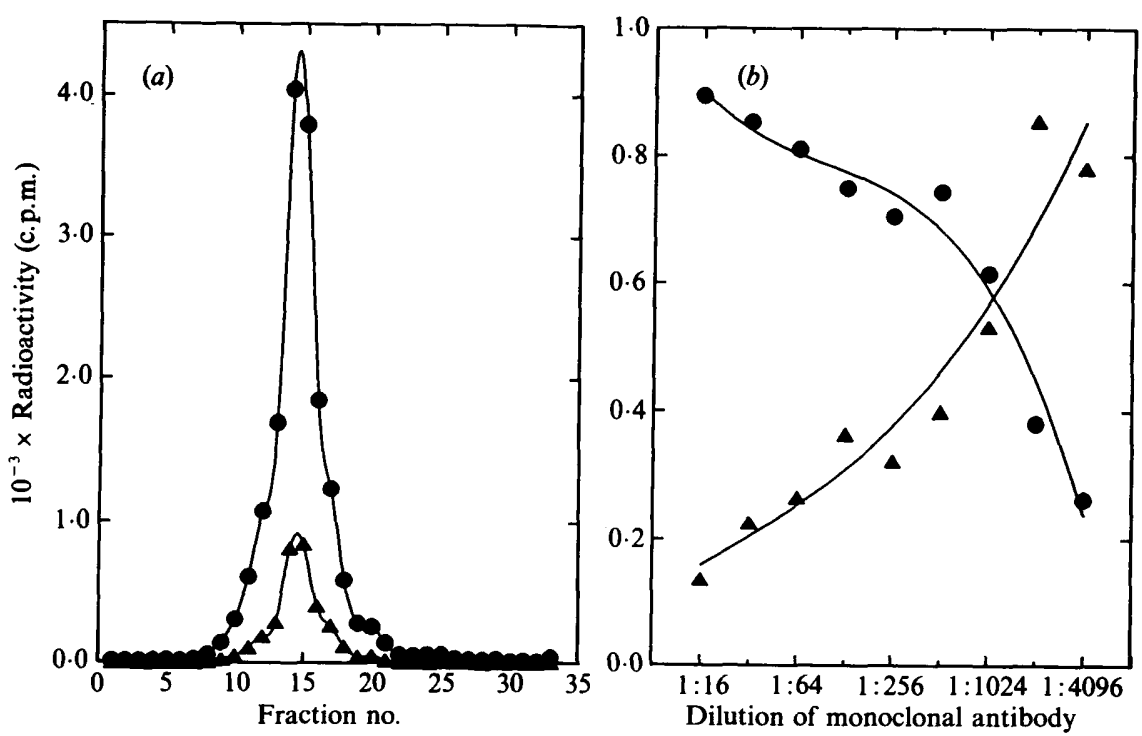

Fig. 6. Co-sedimentation of $\left[{ }^{14} \mathrm{C}\right]$ glycerollabelled LTA and $\left[{ }^{3} \mathrm{H}\right]$ methionine-labelled protein in vesicles $(a)$ and agglutination of $\left[{ }^{3} \mathrm{H}\right]$ methionine-labelled vesicles with monoclonal anti-polyglycerol phosphate (7B11) antibody $(b)$. In $(a)$, $\left[{ }^{3} \mathrm{H}\right]$ methioninelabelled vesicles $\left(1.7 \times 10^{4}\right.$ c.p.m. $)(\bullet)$ were mixed with $\left[{ }^{14} \mathrm{C}\right]$ glycerol-labelled vesicles $\left(3.6 \times 10^{3}\right.$ c.p.m.) $(\Delta)$ and sedimented on a step gradient of metrizamide at $250000 \mathrm{~g}$ for $6 \mathrm{~h}$. Fraction 33 is the bottom of the gradient. In $(b)$, increasing concentrations of monoclonal antibody were used to agglutinate the $\left[{ }^{3} \mathrm{H}\right]$ methionine-labelled (1200 c.p.m.) vesicles containing LTA. The radiolabel $(\bullet)$ on a $0.45 \mu \mathrm{m}$ filter represents the LTA-antibody complex and the radiolabel in the filtrate $(\Delta)$ represents the uncomplexed LTA. from Bacillus subtilis (Fig. 5, lane 4), which is also heterogeneous in size, was determined to have an average of 60 glycerol phosphate residues per chain (J. H. Pollack and F. C. Neuhaus, unpublished observation). These results confirm similar reports by Maurer \& Mattingly (1991) and Leopold \& Fischer (1991) that LTA from a number of bacteria is polydisperse. In $L$. casei chain lengths between 30 and 65 residues were reported. The D-alanine/phosphorus ratio of the LTA was $0.26 \pm 0.06$ for LTA from both vesicles and membranes. In a separate series of experiments, the profile of lipids from the vesicles was identical to that isolated from membranes (data not shown).

The co-secretion of glycerol-labelled constituents and methionine-labelled protein suggested that the isolated vesicles may contain protein as well as LTA (Fig. $4 a, b$ ). Since both radiolabels co-migrated at the same density when the vesicles were purified by density gradient centrifugation (Fig. 6a), it was inferred that the vesicles contain both protein and LTA. This conclusion was supported by agglutinating methionine-labelled vesicles with monoclonal antibodies directed to polyglycerol phosphate. As shown in Fig. 6(b), the anti-polyglycerolphosphate antibody precipitated the labelled vesicles. Similar results were found with $\left[{ }^{14} \mathrm{C}\right]$ glycerol-labelled vesicles (data not shown). Thus, the vesicles described in this paper contain both LTA and protein.

In contrast to the LTA and lipid profiles, the protein profile of vesicles was distinctly different from that found in membranes. Although the vesicles were collected from cells treated with penicillin and could be expected to reflect the composition of the membranes derived from these cells, this result was not observed.
Instead, the protein composition of vesicles consisted of a subset of those found in the membranes with a number of major proteins (four examples of which are indicated by the $\gg$ ) not being found in the vesicles (Fig. 7). Of the five major proteins in the vesicles shown by open arrowheads, one $(\triangleleft 1)$ is present in membranes from both penicillin-treated and untreated cells. Several $(\triangleleft 2, \triangleleft 3$ and $\triangleleft 4)$ appear to reflect the amounts found in membranes from untreated cells, whereas only one $(\triangleleft 5)$ reflects the amount in membranes from penicillintreated cells. Thus, the protein composition of the vesicles does not reflect that of membranes either from cells grown in the presence or in the absence of penicillin. These results also underscore the observation that significant differences result in the protein profiles of membranes when the bacteria are grown in the presence of penicillin (Fig. 7, lane 1 versus lane 2). Thus, the vesicles retain an LTA and lipid composition similar to that of the cytoplasmic membrane; however, their protein composition differs significantly from that of the membrane.

\section{Discussion}

The isolation of vesicles containing LTA from $L$. casei provides a potential acceptor system for studying the in vitro D-alanylation of this polymer (Baddiley \& Neuhaus, 1960; Reusch \& Neuhaus, 1971; Linzer \& Neuhaus, 1973; Taron et al., 1983). L. casei was chosen for our studies because of its well-defined LTA (Fischer, 1988, 1990), lack of wall teichoic acid, and high level of D-alanine-activating enzyme. Mutants of this organism that are deficient in $D$-alanine ester residues show 


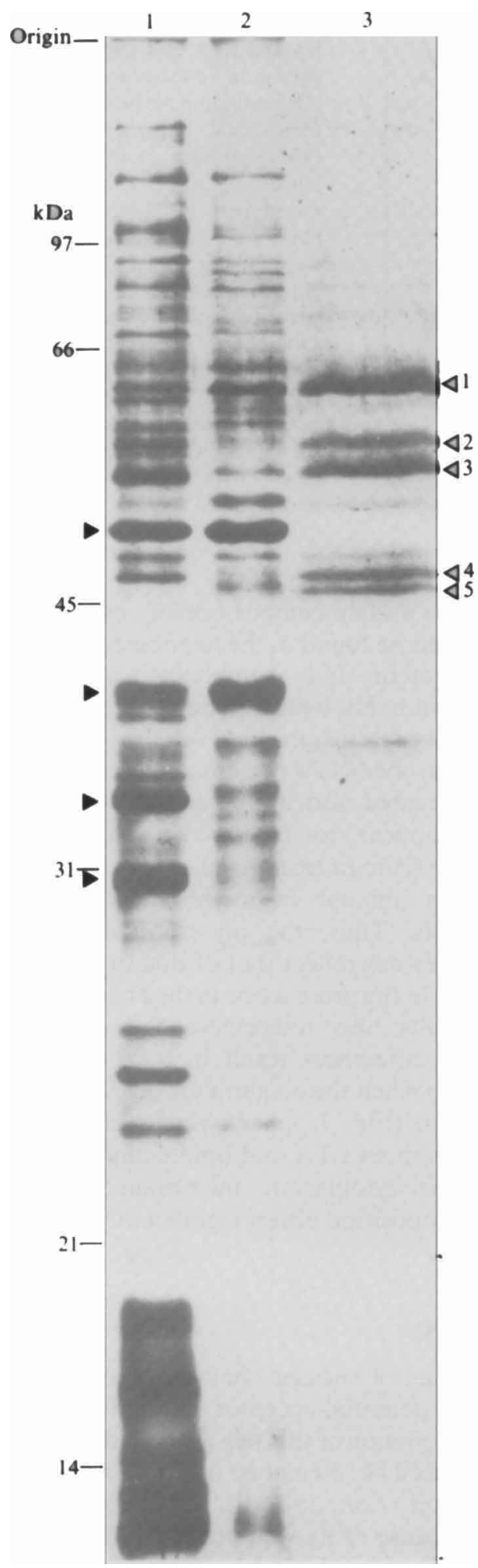

Fig. 7. Protein profile of the vesicles and cytoplasmic membranes from L. casei. Membrane proteins, visualized with Coomassie blue, from cells grown in the absence of benzylpenicillin (lane 1) and in the presence of $5.4 \mu \mathrm{M}$-benzylpenicillin (lane 2 ) are compared with proteins from the vesicles (lane 3). The amount of protein is $16 \mu \mathrm{g}$ in lanes 1 and 2. Proteins that are not secreted into vesicles are designated $\downarrow$. Major proteins secreted into vesicles, designated $\triangleleft$, are described in the text. 
aberrant cell shape (Ntamere et al., 1987). Thus, it was concluded that the D-alanylation system may play a role in defining some of the postulated regulatory properties of this macromolecule (Archibald et al., 1973; Lambert et al., 1975; Fischer et al., 1980, 1981; Koch et al., 1982; Fischer, 1988). With the vesicle preparation described in this paper, it is our goal to address additional features which determine the ability of LTA to accept activated D-alanine. These features may be a function of topology, organization or other membrane constituents.

In previous work, membrane fragments provided the source of endogenous LTA acceptor for D-alanylation (Reusch \& Neuhaus, 1971; Linzer \& Neuhaus, 1973). Attempts to fractionate and reconstitute the acceptor system were unsuccessful (Neuhaus et al., 1974). The only reaction that has been demonstrated with partially purified LTA is the ATP-independent transacylation of D-alanine ester residues in micelles (Childs et al., 1985). The vesicles which are derived from the penicillintriggered secretory process may conserve the organization of the endogenous LTA, and thus provide an in vitro acceptor for the D-alanylation system.

The secretion of glycerol-labelled constituents in response to penicillin has been described in a variety of Gram-positive organisms. For example, in the case of Streptococcus sanguis (Horne \& Tomasz, 1977), cell wall inhibitors caused the release of substantial amounts of LTA and phospholipids into the growth medium under non-lytic, non-bacteriocidal conditions. In a similar manner, inhibition of peptidoglycan synthesis in $L$. casei also promotes the release of glycerol-labelled polymers from this penicillin-tolerant organism. In addressing the mechanism of protein and lipid secretion, it was concluded that the release of LTA in $S$. sanguis and $S$. mutans occurred as vesicular structures in the absence of cell wall disintegration (Horne et al., 1977; Hakenbeck et al., 1983). In the present work, vesicles were also observed at the outer surface of penicillin and D-cycloserine-treated $L$. case $i$. Thus, the enhancement of LTA secretion as vesicles at the wall surface is triggered by the inhibition of wall synthesis.

The secretion of LTA has also been reported in other lactobacilli (Markham et al., 1975; Wicken et al., 1982). In these reports it was suggested that LTA is released from the cell membrane as a transient, non-vesicular component into the culture fluid where it would aggregate to form high molecular mass micelles. Since the critical micelle concentration of LTA is sufficiently low, micelle formation could occur from monomolecular, amphipathic LTA (Courtney et al., 1986). However, in the present work LTA appears to be released as vesicular structures in response to penicillin and D-cycloserine as has been proposed for $S$. pneumoniae and $S$. sanguis (Horne et al., 1977; Hakenbeck et al., 1983). The explanation for this difference may be the result of two mechanisms of secretion: (1) release as monomolecular LTA in the absence of penicillin; (2) release as vesicular structures containing LTA in the presence of penicillin. In $L$. case it is proposed that in the absence of cell wall inhibitors there is a continual turnover and secretion of monomolecular LTA whereas in the presence of penicillin and D-cycloserine vesicular structures are released. Thus, interruption of peptidoglycan synthesis by cell wall antibiotics generates a signal that promotes the secretion of vesicles of LTA and lipid. The nature of this signal is not understood.

In $S$. pneumoniae penicillin stimulates the secretion of a complex set of proteins in vesicles containing LTA (Hakenbeck et al., 1983). It was concluded that these vesicles were derived from the cytoplasmic membrane. In contrast, the protein profile of vesicles from $L$. case $i$ showed only a selected subset of membrane proteins. These results would appear to support the conclusion that the protein composition in the vesicles from this organism may be the result of a selective secretory mechanism and that the vesicles are not the consequence of an extension or continuum of the cytoplasmic membrane. In addition, the limited protein composition further demonstrates that bacteriolysis is not responsible for the formation of these vesicles.

D-Alanyl ester residues play a major role in determining the net charge of lipoteichoic acid (Fischer, 1988, 1990). Under in vitro conditions, a change in the net charge has a major effect on autolytic enzymes. Whether D-alanylation represents an in vivo regulatory system that controls these enzymes has not been established. The mechanism and regulation of the D-alanylation system remains one of the unanswered questions for LTA function. The ability to reconstitute the D-alanylation system with purified, defined vesicles containing LTA will greatly facilitate our understanding of this complex system.

This study was supported in part by Public Health Service grant AI-04615 from the National Institute of Allergy and Infectious Diseases.

We are indebted to Eugene W. Minner for his generous help in the Electron Microscopy Facility of the Department of Neurobiology and Physiology, Northwestern University. We thank Werner Fischer, Michael Heaton and Rabindra Sinha for helpful discussions.

\section{References}

Al-Obeid, S., Gutmann, L. \& Williamson, R. (1990). Correlation of penicillin-induced lysis of Enterococcus faecium with saturation of essential penicillin-binding proteins and release of lipoteichoic acid. Antimicrobial Agents and Chemotherapy 34, 1901-1907.

ALKAN, M. L. \& BEACHEY, E. H. (1978). Excretion of lipoteichoic acid by group $A$ streptococci; influence of penicillin on excretion and loss of ability to adhere to human oral mucosal cells. Journal of Clinical Investigation 61, 671-677. 
ARChibald, A. R., Baddiley, J. \& Heptinstall, J. (1973). The alanine ester content and magnesium binding capacity of walls of Staphylococcus aureus $\mathrm{H}$ grown at different $\mathrm{pH}$ values. Biochimica et Biophysica Acta 291, 629-634.

Baddiley, J. \& NeuHaus, F. C. (1960). The enzymic activation of D-alanine. Biochemical Journal 75, 579-587.

Brautigan, V. M., Childs, W. C., III \& Neuhaus, F. C. (1981) Biosynthesis of D-alanyl-lipoteichoic acid in Lactobacillus casei: D-alanyl-lipophilic compounds as intermediates. Journal of Bacteriology 146, 239-250.

Brissette, J. L. \& Pieringer, R. A. (1985). The effect of penicillin on fatty acid synthesis and excretion in Streptococcus mutans BHT. Lipids 20, 173-179.

Brissette, J. L., Shockman, G. D. \& Pieringer, R. A. (1982). Effects of penicillin on synthesis and excretion of lipid and lipoteichoic acid from Streptococcus mutans BHT. Journal of Bacteriology 151, 838-844.

Cabacungan, E. \& Pieringer, R. A. (1980). Excretion of extracellular lipids by Streptococcus mutans BHT and FA-1. Infection and Immunity 27, 556-562.

CARD, G. L. \& FinN, D. J. (1983). Products of phospholipid metabolism in Bacillus stearothermophilus. Journal of Bacteriology 154, 294-303.

Childs, W. C., III, Taron, D. J. \& Neuhaus, F. C. (1985). Biosynthesis of D-alanyl-lipoteichoic acid by Lactobacillus casei: interchain transacylation of D-alanyl ester residues. Journal of Bacteriology 162, 1191-1195.

Cleveland, R. F., Höltje, J.-V., Wicken, A. J., Tomasz, A., DaneoMOORE, L. \& SHOCKMAN, G. D. (1975). Inhibition of bacterial wall lysins by lipoteichoic acids and related compounds. Biochemical and Biophysical Research Communications 67, 1128-1135.

Cleveland, R. F., Wicken, A. J., Daneo-Moore, L. \& Shockman, G. D. (1976). Inhibition of wall autolysis in Streptococcus faecalis by lipoteichoic acid and lipids. Journal of Bacteriology 126, 192-197.

Courtney, H. S., Simpson, W. A. \& Beachey, E. H. (1986). Relationship of critical micelle concentrations of bacterial lipoteichoic acids to biological activities. Infection and Immunity 51, 414-418.

Diven, W. F., Scholz, J. J. \& Johnston, R. B. (1964). Purification and properties of the alanine racemase from Bacillus subtilis. Biochimica et Biophysica Acta 85, 322-332.

Fiedler, F. \& Glaser, L. (1974). The synthesis of polyribitol phosphate. II. On the mechanism of polyribitol phosphate polymerase. Journal of Biological Chemistry 249, 2690-2695.

FISCHER, W. (1988). Physiology of lipoteichoic acids in bacteria. Advances in Microbial Physiology 29, 233-301.

Fischer, W. (1990). Bacterial phosphoglycolipids and lipoteichoic acids. In Handbook of Lipid Research: Glycolipids, Phosphoglycolipids, and Sulfoglycolipids, pp. 123-234. Edited by M. Kates. New York: Plenum Press.

Fischer, W., KoCH, H. U., Rösel, P. \& Fiedler, F. (1980). Alanine ester-containing native lipoteichoic acids do not act as lipoteichoic acid carrier: isolation, structural and functional characterization. Journal of Biological Chemistry 255, 4557-4562.

FisCHER, W., RöseL, P. \& KoCH, H. U. (1981). Effect of alanine ester substitution and other structural features of lipoteichoic acids on their inhibitory activity against autolysins of Staphylococcus aureus. Journal of Bacteriology 146, 467-475.

FISCHER, W., KOCH, H. U. \& HAAS, R. (1983). Improved preparation of lipoteichoic acids. European Journal of Biochemistry 133, 523-530.

GARFIN, D. E. (1990). One dimensional gel electrophoresis. In Guide to Protein Purification, pp. 425-441. Edited by M. P. Deutscher. San Diego: Academic Press.

HAKENBECK, R., WaKs, S. \& Tomasz, A. (1978). Characterization of cell wall polymers secreted into the growth medium of lysis-defective pneumococci during treatment with penicillin and other inhibitors of cell wall synthesis. Antimicrobial Agents and Chemotherapy 13, 302-311.

Hakenbeck, R., Martin, C. \& Morelli, G. (1983). Streptococcus pneumoniae proteins released into medium upon inhibition of cell wall biosynthesis. Journal of Bacteriology 155, 1372-1381.
HaNCOCK, I. \& BADDILEY, J. (1976). In vitro synthesis of the unit that links teichoic acid to peptidoglycan. Journal of Bacteriology 125, 880-886.

Hebeler, B. H., Chatterjee, A. N. \& Young, F. E. (1973). Regulation of the bacterial cell wall; effect of antibiotics on lipid synthesis. Antimicrobial Agents and Chemotherapy 4, 346-353.

HöltJe, J.-V. \& Tomasz, A. (1975). Lipoteichoic acid: a specific inhibitor of autolysin activity in Pneumococcus. Proceedings of the National Academy of Sciences of the United States of America 72 , 1690-1694.

HoRne, D., Hakenbeck, R. \& Tomasz, A. (1977). Secretion of lipids induced by inhibition of peptidoglycan synthesis in streptococci. Journal of Bacteriology 132, 704-717.

HORNE, D. \& TOMAsz, A. (1977). Tolerant response of Streptococcus sanguis to beta-lactams and other cell wall inhibitors. Antimicrobial Agents and Chemotherapy 11, 888-896.

HoRNE, D. \& Tomasz, A. (1979). Release of lipoteichoic acid from Streptococcus sanguis: stimulation of release during penicillin treatment. Journal of Bacteriology 137, 1180-1184.

JaCkson, D. E., Wong, W., Largen, M. T. \& Shockman, G. D. (1984). Monoclonal antibodies to immunodeterminants of lipoteichoic acids. Infection and Immunity 43, 800-803.

JaCQues, N. A., Hardy, L., KNox, K. W. \& WiCKen, A. J. (1979). Effect of growth conditions on the formation of extracellular lipoteichoic acid by Streptococcus mutans BHT. Infection and Immunity 25, 75-84.

Joseph, R. \& Shockman, G. D. (1975). Synthesis and excretion of glycerol teichoic acid during growth of two streptococcal species. Infection and Immunity 12, 333-338.

Kessler, R. E. \& Shockman, G. D. (1979). Precursor-product relationship of intracellular and extracellular lipoteichoic acids of Streptococcus faecium. Journal of Bacteriology 137, 869-877.

KeSSLER, R. E. \& VAN DE RIJN, I. (1981). Effects of penicillin on group A streptococci: loss of viability appears to precede stimulation of release of lipoteichoic acid. Antimicrobial Agents and Chemotherapy 19, 39-43.

KOCH, H. U., Fischer, W. \& FiEDLER, F. (1982). Influence of alanine ester and glycosyl substitution on the lipoteichoic acid carrier activity of lipoteichoic acids. Journal of Biological Chemistry 257 9473-9479.

LAEMMLI, U. K. (1970). Cleavage of structural proteins during the assembly of the head of bacteriophage $\mathrm{T}_{4}$. Nature, London 227, 680-685.

Lambert, P. A., Hancock, I. C. \& Baddiley, J. (1975). Influence of alanyl ester residues on the binding of magnesium ions to teichoic acids. Biochemical Journal 151, 671-676.

Lambert, P. A., Hancock, I. C. \& BadDiley, J. (1977). Occurrence and function of membrane teichoic acids. Biochimica et Biophysica Acta 472, 1-12.

LeON, O. \& Panos, C. (1990). Streptococcus pyogenes clinical isolates and lipoteichoic acid. Infection and Immunity 58, 3779-3787.

LEOPOLD, K. \& FISCHER, W. (1991). Separation of the poly(glycerophosphate) lipoteichoic acids of Enterococcus faecalis Kiel 27738 , Enterococcus hirae ATCC 9790 and Leuconostoc mesenteroides DSM 20343 into molecular species by affinity chromatography on concanavalin A. European Journal of Biochemistry 196, 475482.

LinZer, R. \& Neuhaus, F. C. (1973). Biosynthesis of membrane teichoic acid: a role for the D-alanine activating enzyme. Journal of Biological Chemistry 248, 3196-3201.

MarkhaM, J. L., K NOX, K. W., Wicken, A. J. \& HeWeTt, M. J. (1975). Formation of extracellular lipoteichoic acid by oral streptococci and lactobacilli. Infection and Immunity 12, 378-386.

MAURER, J. J. \& MATtingly, S. J. (1991). Molecular analysis of lipoteichoic acid from Streptococcus agalactiae. Journal of Bacteriology 173, 487-494.

Min, H. \& Cowman, M. K. (1986). Combined alcian blue and silver staining of glycoaminoglycans in polyacrylamide gels: application to electrophoretic analysis of molecular weight distribution. Analytical Biochemistry 155, 275-285.

NAKANO, M. \& FISCHER, W. (1978). Trihexosyldiacylglycerol and 
acyltrihexosyldiacylglycerol as lipid anchors of the lipoteichoic acid of Lactobacillus casei DSM 20021. Hoppe-Seyler's Zeitschrift für Physiologische Chemie 359, 1-11.

Nealon, T. J., Beachey, E. H., Courtney, H. S. \& Simpson, W. A. (1986). Release of fibronectin-lipoteichoic acid complexes from group A streptococci with penicillin. Infection and Immunity 51, 529-535.

Neuhaus, F. C., Linzer, R. \& Reusch, V. M., JR (1974). Biosynthesis of membrane teichoic acid: role of the D-alanine activating enzyme and D-alanine membrane acceptor ligase. Annals of the New York Academy of Sciences 235, 502-518.

Ntamere, A., Taron, D. J. \& Neuhaus, F. C. (1987). Assembly of D-alanyl-lipoteichoic in Lactobacillus casei : mutants deficient in the D-alanyl ester content of this amphiphile. Journal of Bacteriology 169, 1702-1711.

ReYNolds, E. S. (1963). The use of lead citrate at high pH as an electron-opaque stain in electron microscopy. Journal of Cell Biology 17, 208-212.

ReUSCH, V. M., JR \& Neuhaus, F. C. (1971). D-Alanine :membrane acceptor ligase from Lactobacillus casei. Journal of Biological Chemistry 246, 6136-6143.

Rogers, H. J., Thurman, P. F. \& Burdett, I. D. J. (1983). The bactericidal action of $\beta$-lactam antibiotics on an autolysin-deficient strain of Bacillus subtilis. Journal of General Microbiology 129, 465-478.

Rozgonyi, F., Hahn, H., LABISCHINSKi, H. \& Giesbrecht, P. (1990). A novel labelling procedure of anteiso-fatty acid-containing lipids in staphylococci for investigating the effect of penicillin on lipid release. FEMS Microbiology Letters 71, 11-16.

Shockman, G. D., Kessler, R., CORENTt, J. B. \& Mychajlonka, M. (1978). Turnover and excretion of streptococcal surface components.
In Secretory Immunity and Infection, pp 803-814. Edited by J. R. McGhee, J. Mestecky \& J. L. Babb. New York: Plenum Press.

Straus, D. C., Mattingly, S. J. \& Milligan, T. W. (1977). Production of extracellular material by streptococci associated with subacute bacterial endocarditis. Infection and Immunity 17, 148-156.

Taron, D. J., Childs, W. C., III \& Neuhaus, F. C. (1983). Biosynthesis of D-alanyl-lipoteichoic acid: role of diglyceride kinase in the synthesis of phosphatidylglycerol for chain elongation. Journal of Bacteriology 154, 1110-1116.

Tomasz, A. (1979). From penicillin-binding proteins to the lysis and death of bacteria: a 1979 view. Reviews of Infectious Diseases 1, 434-467.

Tomasz, A. \& Waks, S. (1975). Mechanism of action of penicillin: triggering of the pneumococcal autolytic enzyme by inhibitors of cell wall synthesis. Proceedings of the National Academy of Sciences of the United States of America 72, 4162-4166.

Veerkamp, J. H. (1976). Biochemical changes in Bifidobacterium bifidum var. pennsylvanicus after cell wall inhibition. IX. Metabolism and release of cellular lipids in the presence of antibiotics. Biochimica et Biophysica Acta 450, 277-287.

W AKS, S. \& Tomasz, A. (1978). Secretion of cell wall polymers into the growth medium of lysis-defective pneumococci during treatment with penicillin and other inhibitors of cell wall synthesis. Antimicrobial Agents and Chemotherapy 13, 293-301.

Wicken, A. J., Broady, K. W., AYres, A. \& Knox, K. W. (1982) Production of lipoteichoic acid by lactobacilli and streptococci grown in different environments. Infection and Immunity 36, 864-869.

Wolters, P. J., Hildebrandt, K. M., Dickie, J. P. \& Anderson, J. S. (1990). Polymer length of teichuronic acid released from cell walls of Micrococcus luteus. Journal of Bacteriology 172, 5154-5159. 